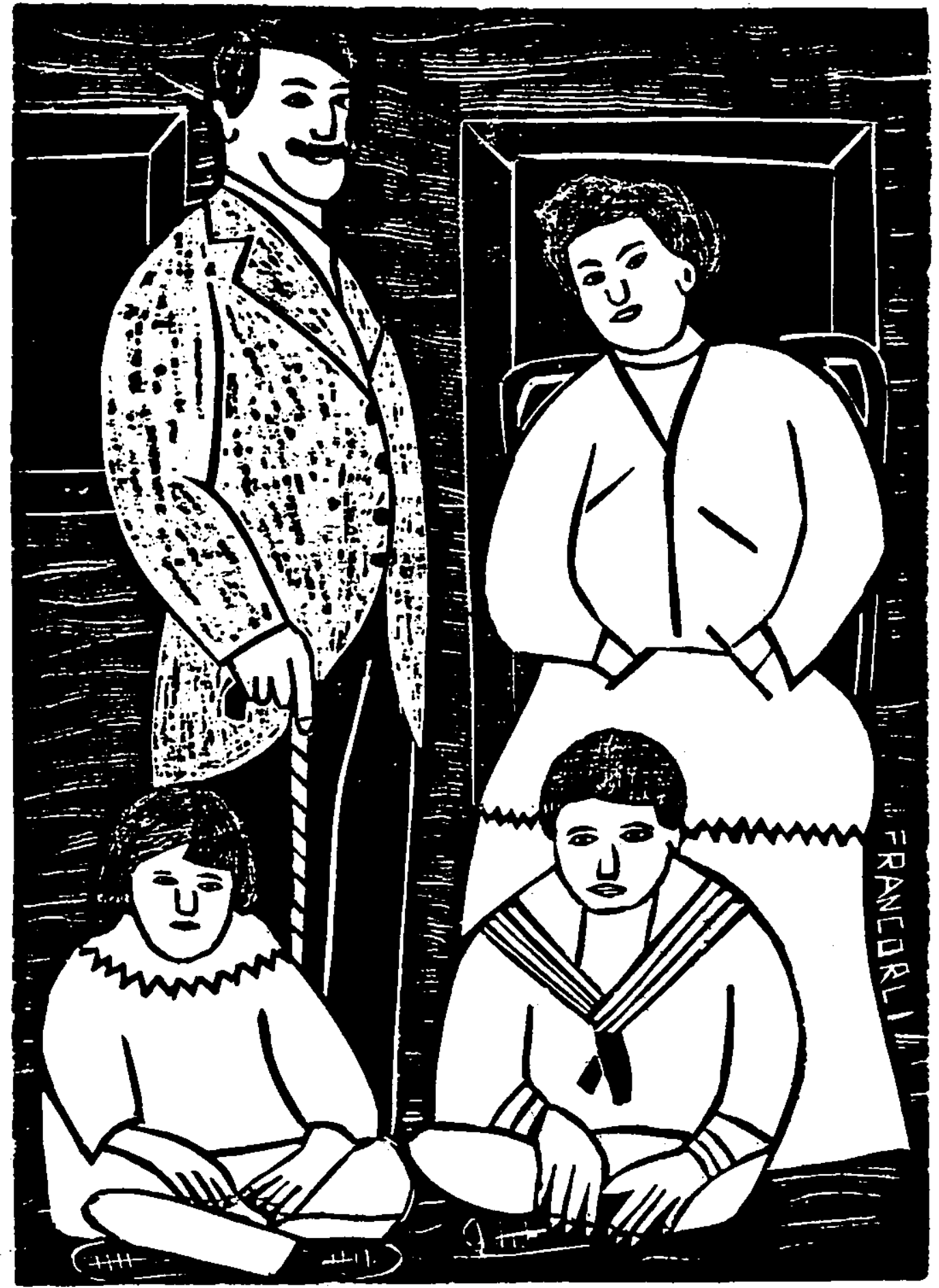

Francorli. Juazeiro do Norte - Ceará. 


\title{
OS PACTOS NA CENA POLÍTICA CEARENSE: PASSADO E PRESENTE
}

\section{César Barreira*}

\begin{abstract}
RESUMO: O ensaio discute as mudanças politicas e econômicas que serviram de base para a construçāo de um novo ciclo de poder no Ceará. Procura entender até que ponto foram rompidas as práticas políticas tradicionais com a subida ao poder, na década de 80, dos "novos empresários".
\end{abstract}

UNITERMOS: Oligarquia no Ceará; clientelismo; coronelismo; partidos politicos; economia; pacto de cooperaçāo.

\section{Introdução}

As fortes marcas oligárquicas dão uma singularidade à política cearense, colocando o estado como um caso paradigmático no contexto das práticas políticas. Os grupos oligárquicos - grupos coronelistas que dominaram a cena politica por quase um século -, imprimiram mecanismos ao poder que deram contornos precisos a uma politica baseada em relaçōes clientelistas e fortemente calcada nos princípios de dependência e paternalismo. Esta é uma opiniāo partilhada por Carone $e^{1}$ e Faoro ${ }^{2}$, que consideram o Estado do Ceará um caso exemplar de poder oligárquico. Nessa mesma direçāo, Oliveira ${ }^{3}$ coloca o Ceará como um dos estados "mais encarniçadamente oligárquicos" do Nordeste.

- Professor da Universidade Federal do Ceará.

1. CARONE, Edgar. A República Velha: instituiçōes e classes sociais. Sāo Paulo, Difel, 1970.

2. FAORO, Raimundo. Os donos do poder: formação do patronato politico brasileiro. Porto Alegre, Globo/Sāo Paulo, Edusp, 1975.

3. OLIVEIRA, Francisco de. O PT dos empresários: anacronismo ou modernidade do Grupo Jereissati. São Paulo, 1993. (Mimeo). 
A politica cearense viveu três grandes ciclos de poder. No inicio do século, com as oligarquias dos Accioli, dos Rabelo e com o padre Cícero. Este é exemplificado por Pereira de Queiroz ${ }^{4}$ como um caso extremo de chefe político local. A partir da década de 60 surge o poder dos três coronéis, Virgilio Távora, Adauto Bezerra e César Cals. No final da década de 80 chega ao poder central do estado o grupo de empresários organizados em torno do Centro Industrial do Ceará (CIC).

Uma das preocupações deste trabalho é discutir as mudanças politicas e econômicas que ocorreram no Ceará e que serviram de base para a construção de uma "nova ordem política", ou um novo ciclo do poder ${ }^{5}$. $O$ importante é entender a que ponto as práticas politicas - coronelistas -, fortemente marcadas por aspectos tradicionais, foram rompidas com a ascensão das elites empresaniais locais. Em outras palauras, entender o que há de novo na política cearense a partir do final da década de 80 implica analisar a seguinte questāo: com a subida ao poder estadual dos "novos empresários", estariam as práticas personalistas/clientelistas/oligárquicas perdendo sua eficácia como meio de reproduçāo do poder?

As rupturas ou descontinuidades nas práticas do poder local não podem ser pensadas isoladamente de um contexto de mudanças que aparecem tanto nas relaçōes de trabalho no campo como nos laços de lealdade e compromisso que subsidiavam os espaços tradicionais da política. Assim, é possivel dizer que as rupturas no poder local que se expressam através de um novo grupo político hegemônico são precedidas por mudanças nas relações de trabalho no campo e uma nova ordem econômica estadual e nacional. As primeiras ajudam a entender a quebra no sistema patrimonial em que os laços pessoais cedem lugar às relaçōes impessoais e racionais; a segunda marca profundamente um novo pacto entre o poder econômico e o poder político, constituindo um novo paradigma de gestão no estado.

Este trabalho deve ser visto como reflexão inicial de um processo politico que, estando ainda em curso, nāo explicitou suas características com nitidez.

\section{Os pactos na cena política cearense}

A história política do Ceará é construída na esteira de pactos políticos. Um estado eminentemente oligárquico não poderia, provavelmente, ter outra trajetória politica. Esses pactos surgem da necessidade de se manter o status quo político

4. QUEIROZ, Maria Isaura Pereira de. O mandonismo local na vida política brasileira e outros ensaios. São Paulo, Alfa-Ômega, 1976.

5. LEMENHE, Maria Auxiliadora de A. L. O(caso) dos coronéis: tradiçāo e modernidade na politica cearense. Brasilia, 1994 - Tese (Doutorado), Universidade de Brasilia. 
e/ou derrotar forças políticas emergentes. Revelam, por um lado, uma demonstração de força e, por outro, o sintoma de algumas fissuras que já se anunciam na hegemonia do poder, apontando para outro rearranjo político. Novas forças são incorporadas dentro de um quadro hegemônico, possibilitando diferentes contornos na base de legitimidade. Esses contornos perpetuam antigas lideranças em um novo momento político.

Durante este século ocorreram três grandes acordos ou pactos entre os grupos políticos hegemônicos. Com a mediação do padre Cícero Romão Batista foi celebrado no dia 4 de outubro de $1911^{6}$ o primeiro grande acordo denominado Pacto dos Coronéis. Tal pacto resultou de uma reunião entre dezenove coronéis ou seus substitutos, representantes da região sul do Estado do Ceará. Para oficializar o acordo foi redigida uma ata assinada por todos os participantes daquela reuniāo. A ata tornou-se uma peça clássica das articulaçōes oligárquicas e da dominação tradicional no sertão.

Naquela ocasião, ficou evidente a ação do entāo governador Antônio Pinto Nogueira Accioli de buscar uma hegemonia politica entre as oligarquias locais. Os pontos constantes na ata foram a tentativa de institucionalizar um "código político" para os coronéis. Se, por um lado, impunham limites ao poder individual dos coronéis, por outro criavam mecanismos para o fortalecimento do sistema oligárquico no estado. Isso fica claro em itens da ata:

"Art. 80 - Manterem todos os chefes aqui presentes inquebrantável solidariedade não só pessoal como política, de modo que haja harmonia de vistas entre todos, sendo, em qualquer emergência, um por todos, todos por um;

"Art. 9" - Manterem todos os chefes incondicional solidariedade política com o excelentíssimo senhor doutor Antônio Pinto de Nogueira Accioli, nosso honrado chefe e, como políticos disciplinados, obedecerem incondicionalmente a suas ordens e determinaçōes".

A solidariedade pessoal era cobrada entre os chefes politicos (coronéis), sendo que para o chefe maior exigia-se solidariedade política. Os mecanismos de disciplina e hierarquia que mantêm a coesāo política aparecem claramente.

Nesse período, o padre Cicero afirmou-se como grande chefe político no estado, ostentando significativa vitória após a derrubada de Franco Rabelo, deposto pela rebeliāo de 1913-14.

"Conservadores e democratas disputavam as boas graças do Padre Cicero, cujas forças eleitorais eram engrossadas por romeiros da Bahia, de Alagoas e

6. Nesse dia Juazeiro do Norte foi elevada à categoria de Vila. 
Pernambuco que vinham votar em Juazeiro nos candidatos daquele sacerdote. A cidade sul-cearense passava pelo maior colégio eleitoral do interior, constituindo um pequeno império absoluto dentro de uma das unidades da Federação Brasileira"7.

Juazeiro era tido como um Estado dentro do estado, onde não chegava a ação da polícia e da justiça.

Os rumos da politica cearense foram novamente traçados, em 1962, por um novo pacto: é sacramentada no estado a União pelo Ceará, articulação feita pelos setores conservadores para barrar o avanço de "novas forças", como o fortalecimento do Partido Trabalhista Brasileiro (PTB), de Carlos Jereissati, e o crescimento de correntes sindicalistas e de grupos mais à esquerda.

"Os Diretónios Regionais do PSD, UDN e PTN" em manifesto dingido ao povo cearense, afirmavam que uniam suas forças para a disputa eleitoral, com candidatos comuns aos postos de governador e vice-governador e senadores da República, com o objetivo de: 1) preservação das instituiçōes democráticas, visadas pela crescente onda demagógica que pretende alcançar o poder para, de posse dele, sacrificar o regime de liberdade em que vivemos; e 2) atender a um plano de trabalho solidamente estruturado, tendo em vista o progresso econômico e a harmonia social"'?

Neste período, o Ceará e todo o Brasil viviam sérias questōes políticas, principalmente em relação ao problema agrário. No editorial do jornal $O$ Povo, do dia 10 de abril de 1962, foi destacada a importância dos proprietários de terra na manutençāo de um quadro "coronelista" e atrasado no Estado:

"Fácil é encontrar motivos para as vacilaçöes do poder público estadual diante desse importante problema [referência à grilagem de terras]. $O$ principal desses motivos é a situação politica. O governo está lutando para obter apoio eleitoral nas áreas tradicionais $e$, pelos modos consagrados, isto é, cortejando os donos de colégios, que são os donos de terra, inclusive terras do Estado. Julga, certamente, que seria um desastre político hostilizar essa gente eleitoralmente poderosa, forçando-a a entregar as terras ilegalmente ocupadas há decênios. (...) Fosse mais audacioso, empreenderia por outro caminho, quebrando o poder dos "coronéis" e buscando apoiar-se nas áreas eleitorais que se fossem liberando por força da redistribuição de terras. Quase podemos estar certos de que a politica agrária anunciada não se definirá no sentido em que a querem impulsionar os interesses do desenvolvimento

7. MONTENEGRO, Abelardo F. Os partidos politicos do Ceará. Fortaleza, UFC, 1980. p. 92.

8. PSD - Partido Social Democrático

UDN - Uniāo Democrática Nacional

PTN - Partido Trabalhista Nacional.

9. MONTENEGRO, Abelardo F. Op. cit. p. 174. 
do estado. Ela será simplesmente uma politica de manutenção do que aí está, uma politica de compromisso com os latifundiários".

Neste editorial, nāo só a estrutura coronelista do Estado é destacada como também os mecanismos do clientelismo político, com suas relaçōes de troca de favores politicos por beneficios econômicos. A política de compromisso do poder público estadual com os donos dos colégios eleitorais, que sāo os donos das terras, foi novamente revigorada em um processo eleitoral.

Dentro desse clima político, a União pelo Ceará conseguiu expressiva vitória na eleição, levando ao governo estadual o coronel Virgílio Távora, da UDN, em coligaçāo com o PTN.

O destaque dado ao "clima de ordem e paz" das eleiçōes de 1962 não encobre as denúncias sobre a influência do poder econômico nas alteraçōes dos mapas de apuração. Essas alteraçōes ocorrem, principalmente, quando os candidatos com vitória já assegurada transferem seus votos a outros que os necessitam para eleger-se. "É a adulteração de mapas eleitorais com a natural conivência das autoridades eleitorais" 10 . Essa vitória construída em cima de um pacto assegurou o coronel Virgílio Távora por mais de duas décadas à frente da política do estado.

Nas eleiçōes de 1958, Virgilio Távora foi derrotado por Parsifal Barroso, da coligação PSD/PTB. Nesse ano, o estado enfrentou uma das maiores secas do século. A máxima do sertão, segundo a qual "governo nāo perde eleição em ano de seca", foi novamente confirmada. Ela revela o conteúdo das campanhas eleitorais que se apresentam não pela "promessa de dias melhores" e sim pela garantia dos recursos federais ou estaduais para obras de cunho assistencial.

Os chefes políticos locais entram em cena controlando

"as residências dos serviços federais. Cabos eleitorais do PSD vinham a ser pagos pelo DNOCS para investigar e coagir os operários, dos quais se indagava se eram eleitores e com qual partido iriam votar. Se eram pessedistas tinham tudo. Se eram udenistas, tinham que aderir, sob pena de serem postos para fora do serviço. Fornecia-se, nos serviços federais, caderneta abonada até fim de outubro de 1958 aos que se comprometessem a votar nos candidatos do PSD e PTB"11.

O jornal O Povo, na ediçāo de 11 novembro de 1958, denuncia o processo fraudulento das eleiçōes daquele ano, apontando alguns aspectos que săo as marcas dos pleitos eleitorais:

10. Idem, ibidem, p. 175.

11. Idem, ibidem, p. 168. 
“a) utilização de 300 caminhōes do DNOCS para transporte de eleitores, na vizinhança das obras federais; b) compra dos cabos eleitorais nos redutos políticos dos adversários do presidente da República; c) compra direta do eleitor mediante dinheiro e roupa nova; d) ameaça dos engenheiros: quem não votasse nos correligionários do presidente da República, seria despedido dos serviços; e) venalidade de alguns chefes".

Nas eleições de 1962, Parsifal Barroso aliou-se a Virgílio Távora na Uniāo pelo Ceará.

Em 1982, com a possibilidade de as forças coronelistas serem derrotadas ou de um enfraquecimento decorrente da divisão entre as três principais lideranças (Virgílio Távora, Adauto Bezerra e César Cals)12 foi oficializado o "acordo dos coronéis", que envolvia uma divisāo dos postos disputados nas eleições e dos cargos de confiança no futuro governo. O pacto dos coronéis, sacramentado no mês de abril pelo entāo presidente da República João Figueiredo, unindo as três forças políticas oligárquicas do Ceará dentro do PDS, não só definiu os resultados das eleiçōes daquele ano como reforçou o processo político local, dominado pela cultura da dependencia. Mais uma vez, a politica cearense é fortemente submetida aos interesses do poder central ${ }^{13}$. As forças oligárquicas são novamente vitoriosas e elegem o secretário de Planejamento do Estado, Luiz Gonzaga Mota, para o cargo de governador.

O PDS obteve quase 80 por cento dos votos no interior do estado e consolidou a estrutura clientelista que reproduzia uma harmonia entre os governos federal e estadual. A manutenção dessa estrutura foi realizada em grande parte através da alusão à miséria do estado e do uso de cabos eleitorais, que viabilizavam a continuidade de uma política conservadora e oligárquica. Os cabos eleitorais conseguiram recompor a clientela eleitoral, que antes era circunscrita ao limite da propriedade, no espaço de um distrito ou povoado. $O$ cabo eleitoral funcionou como mediador entre os eleitores e os politicos, transmitindo as reivindicações de eleitores dispersos ou organizados em municípios aos políticos. Estes elaboravam sua plataforma eleitoral nesse quadro. $O$ cabo eleitoral recuperou o contato pessoal que era realizado pelo próprio candidato ou por coronéis-proprietários.

Dois aspectos intimamente relacionados estão sempre presentes nas caracteristicas das eleições no estado e, mais especificamente, no sertão: o primeiro é que o partido dos proprietários de terras tende a coincidir com o partido da facçāo dominante, que assegura a estrutura clientelista construída ao

12. Esses três lideres eram de fato coronéis do Exército, como o eram em suas práticas politicas. $O$ dado importante é que o título de "coronel" na política, que no imaginário da população sobrepunha-se ao do Exército, nāo era considerado nenhum demérito.

13. BARROS, Hélio; COSTA, Lustosa da. Nordeste: elelçōes. Recife, Massagana, 1985. 
longo do tempo. A meta de estar sempre no poder é o que mantém e dá continuidade ao sistema clientelista cuja existência é calcada na viabilidade de atender a interesses e reivindicaçöes da clientela eleitoral. A alternância levaria à descontinuidade desse atendimento, o que implicaria dificuldades para a reprodução do sistema clientelista.

\section{Fim de um ciclo de pactos}

Nas eleiçōes de 1986, esse ciclo de pactos, acordos e uniōes foi quebrado e um novo momento politico entrou em cena. Um grupo com forte inserção na economia industrial do Ceará ganhou as eleiçōes para o governo do estado e ocupou duas cadeiras no Senado. Nessas eleiçōes, as lideranças tradicionais, os coronéis, sairam derrotados: Adauto Bezerra, candidato a governador, e César Cals, a senador.

O prognóstico feito pelos coronéis era de que seus candidatos perderiam na capital, mas recuperariam a diferença no interior. O resultado mostrou Adauto Bezerra com vantagem sobre o candidato Tasso Jereissati ${ }^{14}$ apenas em 42 municípios dos 152 existentes. No interior, Bezerra obteve 676.451 votos contra 939.589 do oponente.

Número de votos. Votação para governador

Eleição de 1986 - Ceará

\begin{tabular}{llrrr}
\hline Partidos & Candidatos & Votaçāo Capital & Votaçăo Interior & \multicolumn{1}{c}{ Total } \\
\hline PMDB & Tasso & 468.104 & 939.589 & 1.407 .693 \\
PFL & Adauto & 130.864 & 676.451 & 807.315 \\
PT & Pe. Haroldo & 34.975 & 33.069 & 68.044 \\
PS & Quintela & 2.810 & 4.494 & 7.304 \\
Nulos & - & 25.719 & 80.968 & 106.687 \\
Brancos & - & 40.355 & 252.916 & 293.271 \\
Total & & 702.827 & 1.987 .487 & 2.620 .314 \\
\hline
\end{tabular}

O prognóstico dos setores de esquerda era de que o candidato da coligação PT/PSB conseguiria mais de 200 mil votos. Conseguiu, contudo, somente 68.044 , e não atingiu $5 \%$ do total de votos em todo o estado.

Os resultados dessas eleiçōes determinam a subida ao poder de outro gnupo politico que emerge como hegemônico na capital e no interior. O poder no interior

14. Tasso Jereissati, filho de Carlos Jereissati, ex-senador da República eleito pelo PTB em 1962 , independentemente da Uniāo do Ceará. Na edição de 16 de abril de 1962, o jornal O Povo publica que "antes da proclamaçäo dos eleitos, o deputado Carlos Jereissati foi ao Canindé pagar promessas a São Francisco por já se considerar eleito senador e, na ocasiāo, fez doaçāo de um milhão de cruzeiros aos frades". (Apud MONTENEGRO, op. cit). 
não aparece como inteiramente "novo", na medida em que estava fortemente entrelaçado com as forças tradicionais. Essa coligaçăo viabilizou um rearranjo na política local que possibilitou a derrota de um grupo político (hegemônico por quase três décadas) e a entrada em cena de um grupo que se colocava como porta-voz do "novo" e do "moderno". Construiu-se o confronto entre a "força do progresso e da racionalidade" contra a "força da miséria e do atraso".

A campanha política das eleições de 1986 foi reveladora de um outro momento politico local ao delinear o perfil do futuro governo. A principal bandeira dos empresários foi a promessa de acabar com os coronéis, apresentando-os como os principais responsáveis pela condição de miséria do povo cearense. Os seus discursos eram dirigidos contra a miséria, o analfabetismo e o atraso da economia. Como causa dessa situação era apontada a estrutura clientelista que dominava o estado.

A campanha dos coronéis, por outro lado, dava destaque às suas realizaçōes, na tentativa de recuperar a imagem de "grandes benfeitores do sertão", estabelecendo uma relaçāo direta entre voto e gratidāo. Essa prática de ressaltar as realizaçōes como mérito pessoal desvinculada de um compromisso com a gestāo é recorrente. Nas eleiçōes de 1982, ano do acordo dos coronéis, Cals, Távora e Bezerra já se apresentavam como os "três grandes benfeitores do povo". Entretanto, nas eleiçōes de 1986 esse fato ganhou maior proporção. Os debates políticos colocavam em cena, de um lado, a gratidão, a lealdade, as benemerências, o progresso e as realizações, numa alusão direta à ordem vigente; do outro lado, a miséria, o analfabetismo, o clientelismo e o curral eleitoral como uma face a ser negada e superada no novo momento que se apontava.

No dia 13 de junho de 1986 foi publicado no jornal $O$ Povo um artigo bem elucidativo desses debates: "Ninguém vai votar com os coronéis porque vive em curral, mas porque sabe que, com eles no poder, o Ceará experimentou seus melhores dias de progresso e bem-estar. $E$ isso mata de raiva quem não tem prestígio. O que o senhor Jereissati chama de curral é a gratidão do povo. E essa nāo se acaba nunca".

A gratidão é a moeda de troca que equaliza os débitos e os créditos. Como diz Martins"15, o favor aparece "como obrigaçāo moral entre pessoas que não mantêm entre si vínculos contratuais ou, se os mantêm, são eles subsumidos pelos deveres envolvidos em relacionamentos que se baseiam antes de tudo na reciprocidade".

Dentro dos códigos morais oligárquicos, a lealdade mantém fortalecidos os elos dessa cadeia da "política de favores". Os mecanismos tradicionais de

15. MARTINS, José de Souza. O poder do atraso: ensaios de sociología da história lenta. São Paulo, Hucitec, 1994. p. 35. 
realimentação da estrutura clientelista têm a lealdade $e$ a gratidão, no mundo da clientela, como dados recorrentes. As oligarquias tradicionais eram inescrupulosas na utilização desses mecanismos. Os momentos eleitorais eram periodos apropriados para que a memória dos "devedores" fosse realimentada.

A presença de três coronéis do Exército brasileiro no sistema de poder do estado deu singularidade ao campo da política cearense. Tratava-se do reforço e do relacionamento do regime militar com as oligarquias locais. Assim, se o perfeito entendimento dos governos militares com as oligarquias tradicionais do pais é o dado comum, no Ceará esse esquema de sustentação política tem mecanismos especiais. Dos quatro governadores indicados (em 1966, 70, 74 e 78), três foram coronéis do Exército ${ }^{16}$. A forte presença desses coronéis na politica reforçou a oligarquia do estado com uma prática política construida na esteira do clientelismo, do "voto de cabresto" e do "curral eleitoral".

Entretanto, ao lado de formas oligárquicas de manutenção e reprodução do poder conviviam características modernas no âmbito da economia. Muito embora as relaçōes politicas tradicionais fossem a marca do coronelismo, os políticos-coronéis se reproduziam sobre ambigüidades que lhes conferiam a singularidade de fazer conviver o moderno e o atrasado em aparente harmonia. Ao longo de quase três décadas essas lideranças tradicionais e oligárquicas, reforçadas pelo regime militar, ocuparam o papel de mediadoras entre os poderes federal e estadual. $\mathrm{Na}$ mediação, apareceram como os "grandes benfeitores " do estado e provedores das finanças públicas.

Como o estado era o grande empregador, o grande patrāo, a clientela política ultrapassou os limites rurais e se firmou no meio urbano. A máquina estatal se reproduzia em perfeita simbiose entre o público e os interesses da política privada, regada pela mentalidade clientelista de um amplo setor da sociedade encravada entre os funcionánios públicos estaduais e municipais. Os políticos tradicionais e oligárquicos apareciam como indispensáveis e ocupavam o lugar de "provedores", nāo só entre as camadas pobres do meio rural e urbano, mas também em setores da classe média urbana. Os coronéis faziam concessōes, ao mesmo tempo, à clientela rural e aos eleitores urbanos, reproduzindo-se assim como um setor hegemônico. $O$ equilibrio entre a prática política tradicional oligárquica e a concessão clientelistica urbana viabilizava a manutenção desse grupo no poder.

A necessidade do pacto dos coronéis em 1982 foi uma demonstração da vulnerabilidade do sistema oligárquico-coronelista, na medida em que teve de unir forças internamente contraditórias. A opção viável dentro de interesses politicos diversos foi escolher um nome que não trouxesse grandes dividendos políticos para

16. Em 1966 foi indicado Plácido Aderaldo Castelo; em 1970, César Cals; em 1974, Adauto Bezerra; e em 1978, Virgílio Távora. Nesse ínterim, os coronéis ocuparam também cadeiras no Senado e na Càmara de Deputados. 
nenhuma das facçōes ${ }^{17}$. Essas facçōes com práticas políticas semelhantes deixavam aflorar, nos periodos eleitorais, interesses individuais, como a disputa por votos e por cargos de confiança. Tais interesses permitiam ampliar o poder no interior do sistema clientelista. Os três coronéis foram altamente beneficiados pelo regime militar.

Virgilio Távora vinha de uma tradicional familia de politicos na qual se destacaram seu tio Juarez Távora, e seu pai, senador Fernandes Távora, chefe da UDN no final da década de 40. Virgílio foi o grande "provedor do Estado", o elo de ligação entre as finanças públicas federais e estaduais. Encarnou com perfeição a política e o modelo da modernização conservadora implantado pelo regime militar. Adauto Bezerra foi, provavelmente, o de prática mais conservadora, com grande apoio na regiäo sul do estado, e conseguiu imprimir um estilo de governo caracterizado por fortes traços patrimoniais. Entretanto, foi o mais moderno no campo econômico, destacando-se nacionalmente como banqueiro ${ }^{18}$. Hoje, encontra-se afastado das disputas eleitorais, mas continua o homem forte do PFL local. César Cals, sem base local, foi principalmente uma imposição do governo federal para ocupar a direção do estado. O poder decorria do seu relacionamento com Médici e o ministro Andreazza. Suas indicaçōes para governador e, em seguida, para senador biônico afastaram-no da prática eleitoral e determinaram, provavelmente, uma curta vida política sem grandes lastros no poder local.

A oligarquia coronelista não foi desmontada pelo regime militar. Ao contrário, foi realimentada pelos mecanismos do clientelismo baseados na dominação tradicional que mantinha a clientela sob obediência servil. Como diz Martins: "A ditadura militar recente (1964-1984) reconfirmou a impossibilidade de governar sem um entendimento com essas bases municipais organizadas e controladas pelas oligarquias" 19 .

A derrocada desse grupo veio na mesma esteira da derrocada do regime militar. Enquanto este teve fôlego, as práticas tradicionais de exercicio da politica realimentaram a oligarquia com a "política de favores", cultivando fidelidades de grupos políticos.

\section{Antecedentes das transformações políticas}

A análise das rupturas ocorridas no campo da política cearense assume uma conotação mais complexa e menos aparente. Parto do pressuposto de que a vitória

17. Depois de eleito, Gonzaga Mota rompeu publicamente com os coronéis, quebrando laços de lealdade e ferindo o princípio de gratidāo.

18. LEMENHE, Maria Auxiliadora de A. L. Op. cit.

19. MARTINS, José de Souza. Op. cit. p. 32. 
dos empresários nas urnas foi precedida por um desmonte no reinado dos coronéis ${ }^{20}$. Se isso revitaliza, por um lado, a importância da nova elite política na construção do modelo político emergente, por outro, reafirma uma "renovação" das elites locais que dão suporte às transformaçōes.

Dois aspectos me parecem fundamentais para entender as transformaçōes na política cearense ou o rearranjo das elites politicas locais: a mudança nas relaçöes de trabalho no meio rural que implica alteraçōes no sistema de lealdade e dependência; e o novo lugar que a "politica" passa a ocupar entre as novas elites empresariais. No interior desse processo, é gestado um novo quadro político local e o grupo dos "jovens empresários" consolida e dá nitidez às transformações.

A partir principalmente dos anos 60 , as relaçōes de trabalho no meio rural sofrem mudanças. A expulsão dos moradores do interior das propriedades é o dado mais aparente. Os proprietários utilizando-se de vários mecanismos intensificam o processo de expulsão de trabalhadores, diminuindo sensivelmente o número de parceiros/moradores. O fenômeno deu-se concomitantemente à pecuarizaçāo ${ }^{21}$. Ou seja, a diminuição do número de moradores foi proporcional à troca da cultura do algodão pela criação de gado. Na década de 70 o fenômeno torna-se mais nítido com a dramática diminuição do número de parceiros/moradores (categoria típica do sertão cearense) e o aumento gradativo de parceiros que residiam fora da propriedade, separando local de trabalho e moradia: as relaçōes de trabalho perdem seu núcleo patrimonial e cedem lugar à formalização e à impessoalidade. A prolongada seca que assolou o estado entre 1979 e 1983 criou um novo panorama no mercado de trabalho rural. O êxodo da populaçāo rural para as grandes e médias cidades da região esvaziou o campo, possibilitando que os proprietários de terra definissem regras para a contratação dos novos trabalhadores. Este período marcou o incremento do trabalho assalariado - diarista e sazonal - no meio rural.

Esse é um fenômeno importante para se entender a quebra dos laços de dependência. Desaparecendo o "morador de favor" deixa de existir o voto como pagamento de uma divida ao proprietário, que possibilita ao trabalhador uma terra e uma casa para morar. As amarras da fazenda são rompidas e o trabalhador rural fica livre para vender seu voto a quem lhe oferecer melhores condiçōes. $O$ proprietário de terra deixou de ter o controle total sobre o trabalhador rural, na medida em que "dominio" do voto confundia-se com "dominio" do trabalhador.

20. O Jornal do Brasil publicou em 6 de outubro de 1986, o seguinte texto: "Ao longo dos últimos 58 anos, a mais expressiva liderança do Ceará, o coronel da reserva e senador Virgilio Távora, está convicta de que, apesar de todo o alvoroço com o rompimento entre o governador Gonzaga Mota e os três coronéis do estado, e com a eleiçāo da petista Maria Luiza Fontenele para a prefeitura da capital, o estado ainda não gerou um lider capaz de acabar com o reinado do coronelismo".

21. A pecuária no estado passou de 1.354 .338 cabeças de gado bovino em 1960 , para 2.353 .890 em 1980 (fonte: IBGE). 
Uma das formas de dominação do trabalhador dava-se através do voto, considerado "coisa sagrada". Ou seja, a grande obrigação do camponês para com o proprietário era votar no seu candidato. É elucidativo dessa situação um trecho de uma entrevista:

" - Qual é a obrigaçăo que os seus moradores têm para com o senhor?"

- Dar o voto é sagrado e com isso eles ficam me entretendo, me enganando.

- Eles, em 1982, votaram com o senhor?

- Mais da metade deles foi embora porque deram o voto a outro e eu botei pra fora." 22

Votar no candidato do patrão - participar da clientela eleitoral - era a matriz do voto de cabresto, que funcionava como a grande moeda de troca ${ }^{23}$ do sertāo.

A clientela eleitoral, que possibilitava ao grande proprietário manter as benesses do estado, começa a fugir do seu controle pelo fato de os camponeses não residirem mais na propriedade $e$, sobretudo, pela perda da "dependência pessoal" que ocorria no campo.

Nesse quadro de mudanças o camponês passa a ser um novo eleitor cujo voto deve ser conquistado. A percepção das mudanças por parte de políticos provoca alterações sensiveis nos discursos, para acompanhar as mudanças do comportamento eleitoral do camponês e também incorporar as demandas do camponês-eleitor, fora da tutela do proprietário de terra ${ }^{24}$. Nas eleições de 1982 era lugar-comum nos discursos e nas plataformas politicas o respeito aos direitos dos trabalhadores, com destaque à livre organizaçāo dos trabalhadores rurais ou mesmo ao sindicato, como seu legitimo representante, bem como a importância $e$ a necessidade de uma reforma agrária "justa e na lei". O importante da incorporação desses pontos nos discursos de políticos tradicionais são os indicios do novo momento político. A base de sustentaçāo e legitimaçāo da prática coronelista mostra suas debilidades e cria espaço para o novo.

O outro pilar das transformaçōes politicas do estado é o surgimento de um grupo de empresários cearenses defensores de uma "mentalidade política" que se baseia em discursos de racionalidade e competência. Esse grupo era formado basicamente por jovens empresários de famílias tradicionais pertencentes à elite econômica local, uma nova geração ${ }^{25}$ que passa a ocupar cargos-chaves em

22. Grande proprietário rural dos sertöes dos Inhamuns/CE, 5 mar. 1984.

23. QUEIROZ, Maria lsaura Pereira de. Op. cit.

24. BARREIRA, César. Clientelismo e dominação no cenário das eleiçōes. Travessia, Revista do Migrante. São Paulo, a. 2, n. 5, 1989.

25. O dado importante deste grupo é que seus membros são frutos da "geraçāo de 68"; alguns tiveram forte participaçāo no movimento estudantil e experiências e formaçāo acadêmica construídas em outros estados. 
tradicionais grupos econômicos. Essas substituiçōes ocorrem concomitantemente à ampliação das atividades econômicas dos principais grupos empresariais que passam a atuar também em outras regiōes do país. Tais alterações ou ampliações são o cerne de uma racionalidade maior dentro das empresas tradicionais.

Houve também uma modernização e ampliaçāo do parque industrial do estado, que resultou na melhor colocação do Ceará no rank industrial da regiāo Nordeste. Fortaleza não se tornou uma "cidade das chaminés", mas graças principalmente às indústrias têxteis e de confecçōes ocorreu um aumento expressivo no mercado de trabalho local.

Tais alteraçōes no quadro econômico demandavam outra postura da máquina estatal no sentido de gerir as finanças públicas e exigindo outro equilibrio entre prática econômica e prática política. A "competência" e a "racionalidade" deram os rumos da nova administração do estado. Priorizou-se o saneamento das finanças públicas - a folha de salários que era de $52,4 \%$ em 1987 caiu para 30,7\% em $1990^{26}$. A modernizaçāo econômica, que teve efeitos na politica, pode ser reduzida a essas prioridades, ou seja, à racionalização dos custos e à operacionalidade da máquina administrativa. "Talvez seja esse o efeito mais visivel de uma transformação que se notabiliza pela capacidade de gerenciamento de recursos. Trata-se de um tipo de gestão considerada ideal no Brasil dos anos 80: a superação da crise fiscal pelo controle e racionalizaçāo dos custos administrativos" 27 .

As criticas dos empresários às oligarquias tradicionais demarcam a separação entre o novo e o velho, e constituem um tempo de ruptura. A participação de empresários na política não é um dado novo no cenário cearense: Carlos Jereissati, pai de Tasso Jereissati, e José Dias Macedo, pai de Amarilio Macedo28, foram senadores da República, e Expedito Machado, pai de Sérgio Machado, foi deputado federal. O que marca a diferença entre o antigo cenário e o atual, como diz Oliveira, "consiste em empresários, que querem fazer política enquanto empresários, imprimirem à política as caracteristicas da atividade empresarial" 29 .

Essa nova postura frente aos rumos da politica econômica estadual teve seu momento inicial na hegemonia política dos novos empresários do Centro Industrial Cearense (CIC), a partir de 1978. A presidência do CIC passou a ser exercida por

26. OlIVEIRA, Aécio; SMITH, Roberto. O ajustamento do setor público do Ceará. In: A face excludente do governo Ciro Gomes. Fortaleza, Imopec, 1994. (Propostas Alternativas, 2).

27. BARREIRA, Irlys A. F. Modernizaçāo, política e questāo social: diagramas do poder local. In: Caderno do CRH. Salvador, n. 20, 1987.

28. Amarilio Macedo, vice-presidente do Grupo Macedo é considerado um dos principais articuladores do movimento dos empresários. Fez o papel de opositor no grupo, encampando normalmente as propostas consideradas "radicais". Fez política fora da máquina estatal e da política oficial e tinha trànsito livre nos setores mais à esquerda do estado. Era tido como a versaao empresarial de Maria Luiza Fontenele, o que o destacou no interior do grupo dos novos empresários.

29. OLIVEIRA, Francisco de. Op. cit. p. 2. 
membros desse novo grupo: primeiro Beni Veras (1978-1980), atual senador pelo PSDB, seguido por Amarilio Macedo (1980-1981), e posteriormente por Tasso Jereissati (1981-1983) e Sérgio Machado (1983-1985).

$\mathrm{O}$ espaço do $\mathrm{ClC}$ passa a ser cada vez mais politizado, promovendo constantes debates e conferências sobre temas nacionais e locais, com forte demanda por temas políticos. Expressivos intelectuais tidos como de "esquerda" são convidados para proferir conferências. Os empresários, nesse clima de debates, não só gestam suas idéias como opinam sobre a política e a economia do estado. Tasso Jereissati, no dia em que foi eleito presidente do $\mathrm{CIC}$, disse: "O CIC tem um compromisso em niveis estadual, regional e nacional com a formação, o mais rápido possivel, de uma classe política competente e forte, capaz de influenciar $e$ ate assumir o poder" 30 . Foi no interior do $\mathrm{ClC}$ que se construiu uma "identidade empresarial" calcada em dois pilares: o da modernidade e o da racionalidade. Essa passou a ser a marca de antagonismo com as práticas politicas anteriores.

$\mathrm{O} \mathrm{ClC}$ era o quartel-general dos novos empresários que se opunham à Federação das Indústrias do Estado do Ceará - Fiec, considerada antiga e retrógrada. A revista Isto $E$ publicou em 10 de setembro de 1980 uma entrevista com Amarilio Macedo que foi o estopim das controvérsias entre as geraçōes empresariais conservadoras e emergentes. "Fortaleza está a 3.087 quilômetros de São Paulo. Mas quando se fala em renovação de mentalidade empresarial, a distância praticamente deixa de existir. Há quase três anos um grupo de jovens empresánios cearenses assumiu a direção do sexagenário e inexpressivo Centro Industrial do Ceará $(\mathrm{CIC})$ e transformou o que não passava de um agradável local de encontros vespertinos, totalmente submisso à Fiec, em um fónum de debates" 31 . Existe um confronto latente entre o velho $e$ o novo, entre a velha $e$ a nova burguesia industrial. Os pais são as "vitimas sacrificiais" que possibilitam o surgimento do "novo purificado", e notabiliza-se o conflito entre as geraçōes de empresários.

Essa passagem envolve dois processos: o combate, ou a substituiçāo dos coronéis na politica, e a ocupação de antigos espaços da velha burguesia industrial.

A década de 70 e o início da seguinte são o grande palco desse ritual de passagem, representado pela derrocada dos coronéis e o surgimento de fissuras no sistema sócio-político.

A vitória da petista Maria Luiza Fontenele, em 1985, para o cargo de prefeita de Fortaleza nāo pode ser menosprezada, pois aponta um novo momento na politica cearense. Maria Luiza nāo só conseguiu derrotar o candidato dos coronéis

30. Apud MARTIN, Isabela. Os empresários no poder - o projeto politico do CIC (1978-86).

Secretaria da Cultura e Desporto do Estado do Ceará, Fortaleza, 1993.

31. Apud MARTIN, 1. Op. cit. p. 43. 
como também o candidato do PMDB, Paes de Andrade, que teve forte apoio do grupo dos empresários via "movimento pró-mudanças", formado por empresários, profissionais liberais e intelectuais. Esse fato comprova a fragilidade da política tradicional, ainda sem uma implementação mais consistente do grupo empresarial, que se consolidou posteriormente em torno do PSDB.

A partir desses dados é possivel dizer que a vitória do grupo dos "novos empresários" nas eleiçōes de 1986 ocorreu com a derrota gradativa dos coronéis e a falta de alternativa diante de outro momento politico.

A indicação de Tasso Jereissati para concorrer às eleiçōes de 1986 para governador partiu do então governador Gonzaga Mota, depois de várias tentativas de rearticular o pacto dos coronéis, de 1982, que não se viabilizou porque Mota exigiu que ele próprio indicasse o candidato a governador. Havia, também, a tentativa de manter no Ceará a Aliança Democrática formada pelo PMDB e PFL. É então que surge o nome de Tasso Jereissati, que já tinha declarado, à época das Diretas-Já, que o plano dos empresários progressistas era dar condiçōes para o bom desempenho dos "políticos profissionais". Segundo suas próprias palavras, mudou de idéia ao constatar

"que a sucessão no Ceará estava caminhando para uma solução que representaria um retrocesso de vinte anos, voltando novamente à politica dos coronéis; isso nos motivou a ingressar na disputa eleitoral. Na campanha de Tancredo, o coronel Adauto Bezerra parecia ter dado um passo à frente ao adenir àquela candidatura. No momento em que ele recuou da posição para recompor a triade dos coronéis - com Virgilio Távora e César Cals - ficou claro que, se todas as forças novas e progressistas nāo dessem as mãos, o Ceará estaria dando um passo atrás enquanto o Pais dava um passo à frente" 32 .

A vitória de Tasso Jereissati pelo PMDB foi representativa em todo o Estado, elegendo também dois senadores, doze deputados federais (o PFL elegeu oito) e 24 deputados estaduais (o PFL conseguiu eleger dezoito).

O quadro das eleiçōes municipais de 1988 não é definidor das mudanças: o PMDB elegeu 60 prefeitos, o PFL, 57 e o PDS, 28.

O grupo dos empresários sai novamente vitorioso em 1990: coloca Ciro Gomes (PSDB) no cargo de governador e consegue ocupar a vaga de senador; elege ainda dez deputados federais de um total de 22 , e 21 deputados estaduais de um total de 46.

O dado interessante é que nas eleições municipais de 1992, o PSDB, em aliança com o PDT, elege 118 prefeitos de um total de 184 municípios.

32. Depoimento de Tasso Jereissati. Apud MARTIN, I. Op. cit., p. 52. 
Se por um lado esse quadro eleitoral mostra uma nova composição politica com vitórias sucessivas do grupo dos empresários, por outro, demonstra como prevalecem os laços de fidelidade que se sobrepōem às opçōes ideológicas partidárias. A frase que caracteriza a politica tradicional, "Eu năo mudo, quem muda é o governo", persiste no imaginário dos eleitores e em segmentos variados da politica.

\section{Novas práticas discursivas}

O discurso dos jovens empresários sempre remete à necessidade de apressar as transformaçōes sociais e politicas do estado. Nessa idealizaçăo existe um discurso cuja ideologia baseia-se na idéia de que as rupturas sociais podem ocorrer subitamente. Tasso Jereissati coloca como centro de sua campanha politica a luta contra o clientelismo, que é, para ele, sinônimo de coronelismo. "O essencial, o clientelismo político, este nós vamos atacar no dia 15 de março [dia da posse]. No dia 16 não haverá mais clientelismo politico" 33 .

A luta "contra o tempo" está no centro das rupturas propostas, no cerne das dicotomias anacrônico-moderno, conservador-progressista, antigo-novo. Os jovens empresários são os porta-vozes do novo tempo: "Pelo sistema tradicional, se as idéias não rompessem com todos os valores, não teriam nenhuma chance. Se fôssemos medir as forças, um [candidato] tinha 130 prefeitos e o outro tinha 15. Cento e trinta sempre ganha de 15 . Era preciso colocar no processo idéias novas que fossem capazes de desestabilizar a ordem" 34 .

As idéias novas eram a grande arma dos "novos empresários" frente ao sistema de compromissos com as faç̧öes locais, municipais, em que a ordem coronelista estava encravada. Se essa ordem era adversa aos empresários, por ser uma prática política secular, a sua negaçāo, tornando-a "a vítima sacrificial" do processo, era a possibilidade de afirmação da nova elite política.

As críticas ao coronelismo por parte dos novos empresários remontam ao início da década de 80. Em discurso no ano de 1982, Tasso Jereissati ressaltou o caráter anacrônico do coronelismo e conclamou o governador eleito, Gonzaga Mota, a "romper com este vício" 35 .

A nova elite político-empresarial vai se firmando na política cearense, tornando-se hegemônica com um discurso modernizante e a favor da justiça social. Para Tasso, "(...) não há nenhuma perspectiva a longo prazo para o empresário

33. Depoimento para a revista Veja de 10 de dezembro de 1986. Apud MARTIN, I. Op. cit.

34. Entrevista com Sérgio Machado em 31 de dezembro de 1992. Apud MARTIN, 1. Op. cit.

35. O dado pitoresco deste discurso é que se encontravam na platéia os três coronéis: Virgilio Távora, Adauto Bezerra e César Cals. Segundo a imprensa local, Virgilio Távora teria ficado muito incomodado com o tom do discurso demonstrando, na ocasiāo, o seu descontentamento. 
sem a solução dos problemas sociais do pais. Ou todos resolvemos juntos o problema da justiça social ou todos juntos pereceremos. A bandeira contra a miséria deve ser erguida e defendida por todos nós"36.

$\mathrm{Na}$ perspectiva de consolidar um capitalismo humanitánio ${ }^{37}$, a regra básica é lutar contra a miséria social, diminuindo as diferenças de renda. A tese é elementar: "nāo existe capitalismo sem consumidor"38, ou "nós acabamos com a miséria ou por ela seremos destruídos" 39 .

Nessas colocaçōes estavam implicitas criticas à politica industrial do governo federal, principalmente em relação ao crescimento do processo de estatizaçāo e do centralismo do estado como planejador. A identificação com o Grupo dos Oito ${ }^{40}$, de Sảo Paulo, foi imediata, criando fortes laços com os empresários paulistas. Isso não só favoreceu a ampliação dos espaços econômicos do grupo cearense como também deu a ele maior respaldo político local. $O$ engajamento dos jovens empresários na política nacional foi imediata, principalmente na participação do processo de abertura política.

Internamente, no estado, o grupo dos jovens empresários amplia e consolida seus espaços no campo da politica, aproximando-se dos "politicos profissionais". Nesse sentido, ganha destaque a incorporação ao grupo de dois politicos pertencentes às "tradicionais famílias políticas" e com passagem por partidos politicos conservadores de direita: Ciro Gomes e Lúcio Alcântara ${ }^{41}$. Essas incorporaçōes não só ampliam os espaços eleitorais como também demonstram a não impermeabilização desse grupo às regras do jogo da política.

Nessa curta trajetória, um processo ainda em curso, as dúvidas e incertezas dão o colorido nebuloso do novo momento politico. No primeiro momento, para

36. O Povo, Fortaleza, 7 nov. 1981.

37. "O capitalismo humanitário que nós defendiamos era nada mais, nada menos, que a socialdemocracia: o live mercado com a presença forte da live iniciativa e tendo o Estado como regulador das desigualdades sociais e do desequilibrio entre as pessoas e entre as regiöes. Um Estado que tivesse um viés fortemente social, promovendo, em vez de empresas, educaçäo; ao invés de empresas, saúde, por exemplo, dando condiçōes aos mais desfavorecidos pela sorte de ter as oportunidades mínimas necessárias ao cidadāo. Isto que nós delendiamos era diferente do liberalismo, que é a ausência total do Estado". (Tasso Jereissati, em entrevista concedida em 15 de dezembro de 1992. Apud MARTIN, I. Op. cit.)

38. Tasso Jereissati em depoimento para a revista Veja, São Paulo, 10 dez. 1986.

39. Amarilio Macedo, para o jornal O Povo, Fortaleza, 19 jan. 1980.

40. Este grupo era constituido de oito empresários nacionais que delendiam a abertura democtática Claúdio Bartella, José Mindlin, Severo Gomes, Antônio Ermíno de Moraes, Paulo Villares, Paulo d'Arrigo Velhinho, Laerte Setúbal e Jorge Gerdal Johannpeter. O grupo foi apontado pelo Jornal A Gazeta Mercantil, de São Paulo, como porta-voz do empresariado brasileiro.

41. Ciro Gomes pertence a uma tradicional familia de politicos da regiāo norte do estado, tendo passado pelo PDS e pelo PMDB. Foi eleito prefeito de Fortaleza em 1988 e governador do Ceará em 1990. Lúcio Alcántara é filho do antigo político Valdemar de Alcántara, e pertenceu ao PFL e ao PDT. Foi eleito vice-governador em 1990 e senador em 1994. 
- grupo dos jovens empresários balizados pelos principios de modernidade $e$ racionalidade, o estado é visto como um continuum das empresas. Nesse sentido, os princípios de eficácia e racionalidade do mundo empresarial são transferidos, mecanicamente ou sem nenhuma mediação política, para a máquina estatal. $O$ estado deveria ser administrado como uma empresa: máquina enxuta e setores não rentáveis desativados. Pela lógica, a vocação econômica do estado não era a agricultura, mas o turismo, $e$ as indústrias comandariam o soerguimento econômico do Ceará. A agricultura perdeu paulatinamente o seu lugar de absorção de mão-de-obra, e também o Estado deixou de ser o "grande empregador" de serviço público para a classe média 42 . Com esta politica o mercado de trabalho foi fortemente atingido.

Tais medidas trazem fortes dividendos sociais e politicos. O êxodo para a capital em busca de empregos cresceu muito por parte da população rural, $e$ também aumentou o descontentamento dos funcionários públicos estaduais com o achatamento salarial e o número de demissöes. Tal situaçāo impôs limites politicos à nova elite, que agora tem de trabalhar cada vez mais pela via da mediação politica. A sua posição hegemônica não pode ser mantida somente pelo lado da racionalidade econômica. A legitimidade que decorre, em grande parte, da adequação às regras do jogo político, aparece como um dado fundamental para a reprodução do grupo no poder.

Os pactos politicos serviram ao longo da história para manter os grupos oligárquicos no poder. Nas últimas décadas esses pactos definiram, principalmente, os rumos eleitorais do estado. Em 1991 foi celebrado um pacto dentro dos princípios de modernidade que deu o direcionamento para a politica local $e$ ofereceu sustentáculos para as novas elites políticas. O denominado "pacto de cooperação" foi instalado pelo entāo governador do estado e um grupo de empresários, e tinha como objetivo central discutir alternativas para os graves problemas estaduais. Seus membros destacam que a novidade desse pacto é a participação da sociedade civil nos debates, em busca de soluçōes "participativas". Para as novas elites, o pacto quebra a estrutura clientelista na medida em que retira o governo do centro das decisōes, o que antes o deixava "poderoso e dadivoso". O pacto é considerado um dos instrumentos de participaçāo e transferência que o governo tem para discutir juntamente com a sociedade o seu futuro. Isso é apontado como um dos mecanismos que quebraria a marca da dependência paternalista. $O$ "pacto de cooperação" tem sido um dos sustentáculos políticos das novas elites.

42. Este aspecto pode explicar a derrota do candidato dos empresários para a prefeitura de Fortaleza em 1992, e também a derrota de Tasso Jereissati, em Fortaleza, para governador. 
As controvérsias em torno do velho e do novo demarcaram complexidades analíticas, além dos discursos e classificações que acompanham as disputas político-partidárias.

Assinalar as rupturas implica compreender que a vigência de um círculo politico depende do anterior. As marcas do passado no presente, ou as marcas do presente no passado, constituem ainda um espaço aberto a investigaçōes.

\section{Referências Bibliográficas}

BARREIRA, César. Trilhas e atalhos do poder: conflitos sociais no sertāo. Rio de Janeiro, Rio Fundo, 1992.

BOBBIO, Noberto. O futuro da democracia: uma defesa das regras do jogo. Rio de Janeiro, Paz e Terra, 1986.

BOURDIEU, Pierre. Les modes de domination. Actes de la recherche en sciences sociales.

Paris, n. 2-3, 1976. Le sens pratique. Paris, Les Éditions de Minuit, 1980.

DELA CAVA, Ralph. Milagre em Juazeiro. Rio de Janeiro, Paz e Terra, 1976.

GONDIM, Linda M. P. Os governos das mudanças no Ceará: um populismo weberiano? Caxambu, XIX Encontro da ANPOCS, 1995.

MARTINS, José de Souza. A chegada do estranho. São Paulo, Hucitec, 1993.

PANG, Eul-Soo. Coronelismo e oligarquia (1899-1934). Rio de Janeiro, Civilização Brasileira, 1975.

SOUZA, Maria José. Aspectos políticos do Ceará na primeira República. Salvador, 1973. Dissertação (Mestrado) - Universidade Federal da Bahia.

VIDAL, Márcia. Imprensa e poder - o I e o II Veterados (1963/1966 e 1979/1982 no Jornal "O Povo"). Fortaleza, Secretaria da Cultura e Desporto do Estado do Ceará, 1994.

\section{PACTS IN CEARÁ'S POLITICAL SCENE: PAST AND PRESENT}

ABSTRACT: The present essay discusses the political and economical changes that served as a base for the setting of a new cycle of power in Ceará. It also considerate the extent of the rupture in traditional political practices that occurred after the emergence of the "new businessmen" in the eighties.

KEYWORDS: Oligarchies in Ceará; clientelism; colonelism; political parties; cooperation pacts. 